\title{
Communication \\ Cytotoxic Labdane Diterpenes from Hedychium ellipticum Buch.-Ham. ex Sm.
}

\author{
Sineenard Songsri and Nuchnipa Nuntawong * \\ Department of Chemistry and Center for Innovation in Chemistry, Faculty of Science, Chiang Mai University, \\ Chiang Mai 50200, Thailand; n_boxtree@hotmail.com \\ * Correspondence: nuchnipa.n@cmu.ac.th or nuchnipa@hotmail.com; Tel.: +66-88-002-6124
}

Academic Editors: Quan-Bin Han and Jian-Xin Pu

Received: 11 May 2016; Accepted: 3 June 2016; Published: 9 June 2016

\begin{abstract}
In order to reveal the constituents and their biological activities, we carried out a phytochemical study on Hedychium ellipticum Buch.-Ham. ex Sm. (Zingiberaceae). Ten labdane diterpenoids (1-10) were isolated from the rhizomes of $H$. ellipticum for the first time. Their structures were identified on the basis of spectroscopic analyses including two-dimensional NMR and comparison with literature data. All of these compounds were evaluated for their antimycobacterial activity against Mycobacterium tuberculosis and cytotoxicity against KB, MCF7, NCI-H187 and Vero cells. The result showed that compounds $\mathbf{1}$ and $\mathbf{7}$ exhibited moderate activity against Mycobacterium tuberculosis and compounds 4, 6 and $\mathbf{7}$ displayed remarkable cytotoxic activity. This is the first report on the presence of all compounds in H. ellipticum and the first time that their structure activity relationship has been discussed.
\end{abstract}

Keywords: Hedychium ellipticum; labdane-type diterpene; cytotoxic activity; antimycobacterial activity

\section{Introduction}

Several species of Hedychium are used widely in traditional medicines for treatment of skin diseases, stomach ailments, cough and apoplexy, and as an analgesic, anti-inflammatory, antimicrobial and anti-rheumatic treatment [1,2]. Previous phytochemical studies on Hedychium species revealed the presence of diarylheptanoids, sesquiterpenes and diterpenes, some of which showed hepatoprotective effects [3], antiinflammatory activities [4] and cytotoxicity against various cancer cells [5-12]. Hedychium ellipticum Buch.-Ham. ex Sm. (Zingiberaceae), cultivation from Doi Suthep overlooking Chiang Mai in Thailand has bright green rolled bracts. No detailed phytochemical and pharmacological investigation on H. ellipticum has been reported, except for a report on the chemical composition of leave and rhizome essential oils, which showed that $(E)$ - nerolidol and 1,8-cineole were the major constituents $[13,14]$. The methanolic extracts of rhizomes showed potent activity to inhibit the biosynthesis of leukotriene $\mathrm{B}_{4}$ in bovine polymorphonuclear leukocytes and the essential oils exhibited moderate-to-good $\mathrm{Fe}^{2+}$ chelating activity [15]. In our preliminary investigation on the bioactivities of Hedychium plants, we found that the crude $n$-hexane and $\mathrm{CH}_{2} \mathrm{Cl}_{2}$ extracts of $\mathrm{H}$. ellipticum rhizomes showed moderated antimycobacterial activity against Mycobacterium tuberculosis and cytotoxic activity against human cancer cell lines. Therefore, the aim of the present work is to determine the chemical constituents from the rhizomes of $\mathrm{H}$. ellipticum and to evaluate their antimycobacterial activity against Mycobacterium tuberculosis and cytotoxicity against KB, MCF7, NCI-H187 and Vero cells. The structure-activity relationships of all isolated compounds were also reported.

\section{Results}

Phytochemical investigation of the rhizomes of $\mathrm{H}$. ellipticum resulted in the isolation of 10 labdane-type diterpenes: coronarin E (1) [10], (E)-15,16-bisnorlabda-8(17),11-dien-13-one (2) [16], 
(E)-14,15,16-trinorlabda-8(17),11-dien-13-oic acid (3) [3], villosin (4) [10], (E)-labda-8(17),12-dien15,16-dial (5) [3], 15-methoxylabda-8(17),11,13-trien-15,16-olide (6) [17], 16-hydroxylabda-8(17),11,13trien-15,16-olide (7) [17], coronarin D (8) [8], zerumin A (9) and zerumin B (10) [18] (Figure 1). Their structures were determined by spectroscopic methods and by comparison of their spectral data with those reported in the literature. These compounds are known but they were isolated from this plant for the first time. This phytochemical investigation of $H$. ellipticum has shown that its chemistry differs from other species of Hedychium. Compounds 1, 4, 5, 6 and 8 were isolated from the rhizomes of Hedychium coronarium J. Koenig [3-5,8,12], Hedychium villosum Wall. [1] and Hedychium gardnerianum Sheppard ex Ker Gawl. [10]. Interestingly, compounds 2, 3, 7, 9 and 10 have not been reported from any species of the Hedychium and could be regarded as an important chemotaxanomic marker. All isolated compounds were evaluated for their antimycobacterial activity against Mycobacterium tuberculosis and cytotoxicity against three human tumor cell lines, human oral cavity cancer cell (KB), human breast cancer cell (MCF7) and human small cell lung cancer cell (NCI-H18) and non-cancerous (Vero) cell lines. The results of the antimycobacterial activity against Mycobacterium tuberculosis of all compounds are given in Table 1. Compounds $\mathbf{7}$ and $\mathbf{1}$ exhibited moderate activity against Mycobacterium tuberculosis with MIC 6.25 and $12.5 \mu \mathrm{g} / \mathrm{mL}$, respectively, while compounds $\mathbf{2 , 3 - 6}$, and 8-10 were inactive. All compounds exhibited over 20-fold inferior than standard drug streptomycin. To the best of our knowledge, this is the first report for the antimycobacterial activity of all compounds. In a comparison of all compounds, furan ring or $\alpha, \beta$-unsaturated $\gamma$-lactone ring is essential for the antimycobacterial activity. Change in an $\alpha, \beta$-unsaturated $\gamma$-lactone ring did affect the activity as indicated in the case of compounds 4, 6, 7 and 10. The hydroxyl group at C-16 significantly enhanced the activity of compound 7 , which suggested that the relative hydrophilicity of this part of the molecule contributes to the activity. However, lack in activity of compound 10, implying that the orientation of cyclic hemiacetal $\alpha, \beta$-unsaturated $\gamma$-lactone is also influenced the activity. Although the structure-activity relationships of these compounds were not conclusively determined, this finding provided a useful starting point for antimycobacterial activity of labdan-type diterpenoids.

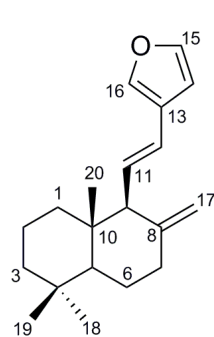

1<smiles>[R]C(=O)/C=C/C1C(=C)CC[C@H]2C[C@H](C)CCC[C@]12C</smiles>

$2 \mathrm{R}=\mathrm{CH}_{3}$ $3 \mathrm{R}=\mathrm{OH}$

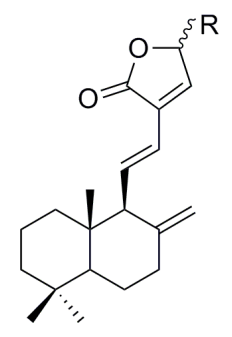

$4 \mathrm{R}=\mathrm{H}$ $6 \mathrm{R}=\mathrm{OCH}_{3}$<smiles>C=C1CC[C@H]2C(C)CCCC2(C)C1/C=C/C1=CC(=O)O[C@@H]1O</smiles>

7

10<smiles>C=C1CC[C@H]2C(C)CCC[C@]2(C)[C@H]1CC(O)C1=CC(O)OC1=O</smiles><smiles>[R]C1=C2CC[C@H]3[C@H](C)CCC[C@]3(C)[C@H]2CC=C1C=O</smiles>

$5 \mathrm{R}=\mathrm{CHO}$

$9 \mathrm{R}=\mathrm{COOH}$

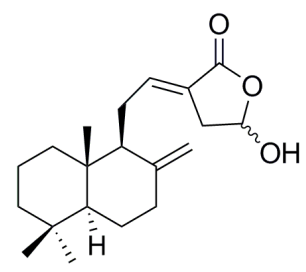

8

Figure 1. The structures of compounds 1-10 from H. ellipticum. 
Table 1. Anti- Mycobacterium tuberculosis H37Ra (Anti-TB) and cytotoxic activities of isolated compounds.

\begin{tabular}{|c|c|c|c|c|c|c|c|c|}
\hline \multirow{2}{*}{ Compounds } & \multirow{2}{*}{$\frac{\text { Anti-TB }}{(\mathrm{MIC}, \mu \mathrm{g} / \mathrm{mL})}$} & \multicolumn{4}{|c|}{ Cytotoxicity $\left(\mathrm{IC}_{50}\right)$ in $\mu \mathrm{g} / \mathrm{mL}(\mu \mathrm{M})$} & \multicolumn{3}{|c|}{ Selectivity Index } \\
\hline & & KB & MCF7 & NCI-H187 & Vero Cell & KB & MCF7 & NCI-H187 \\
\hline Coronarin E (1) & 12.5 & $9.67(34.00)$ & Inactive & $18.06(63.50)$ & $25.37(89.20)$ & 2.6 & 0.5 & 1.4 \\
\hline (E)-15,16-Bisnorlabda-8(17),11-dien-13-one (2) & Inactive & $36.99(142.05)$ & $49.22(189.02)$ & $21.67(83.22)$ & Undetectable $^{2}$ & 1.4 & 1.0 & 2.3 \\
\hline (E)-14,15,16-Trinorlabda-8(17),11-dien-13-oic acid (3) & Inactive & Inactive & Inactive & $49.23(187.64)$ & Undetectable $^{2}$ & - & - & 1.0 \\
\hline Villosin (4) & Inactive & $4.1(13.65)$ & $8.5(28.29)$ & $0.12(0.40)$ & Undetectable $^{2}$ & 12.2 & 5.9 & $>416.7$ \\
\hline (E)-Labda-8(17),12-dien-15,16-dial (5) & Inactive & $29.05(96.05)$ & $22.55(74.56)$ & $11.17(36.93)$ & $22.52(74.46)$ & 0.8 & 1.0 & 2.0 \\
\hline 15-Methoxylabda-8(17),11,13-trien-15,16-olide (6) & Inactive & $23.82(72.08)$ & $49.16(148.77)$ & $0.9(2.72)$ & 45.65 (138.14) & 1.9 & 0.9 & 50.7 \\
\hline 16-Hydroxylabda-8(17),11,13-trien-15,16-olide (7) & 6.25 & $0.91(2.75)$ & $2.89(8.75)$ & $0.72(2.18)$ & $5.37(16.25)$ & 5.9 & 1.9 & 7.5 \\
\hline Coronarin D (8) & Inactive & $40.01(125.64)$ & $16.25(51.03)$ & $25.72(80.77)$ & $48.89(153.53)$ & 1.2 & 3.0 & 1.9 \\
\hline Zerumin B (10) & Inactive & $13.13(39.26)$ & $13.28(39.71)$ & $6.14(18.36)$ & $24.69(73.82)$ & 1.9 & 1.9 & 4.0 \\
\hline Ellipticine ${ }^{1}$ & - & $0.302(1.23)$ & - & $0.44(1.79)$ & $1.345(5.46)$ & 4.5 & - & 3.1 \\
\hline Doxorubicin $^{1}$ & - & $0.117(0.22)$ & $0.663(1.22)$ & $0.053(0.10)$ & - & - & - & - \\
\hline
\end{tabular}

${ }^{1}$ Standard drug; ${ }^{2}$ Undetectable at concentration $\leqslant 50 \mu \mathrm{g} / \mathrm{mL}$ (or 192.01, 190.57 and $166.43 \mu \mathrm{M}$ for compounds 2, 3 and 4, respectively). 
In previous studies, some labdane diterpenes from the species of Hedychium were found to show cytotoxicity. Therefore, compounds 1-10 were also evaluated for cytotoxic activities against three cancer cell lines: human oral cavity cancer cell (KB), human breast cancer cell (MCF7) and human small cell lung cancer cell (NCI-H18) (Table 1). All of the 10 labdane-type diterpenoids exhibited generally stronger cytotoxic effect against NCI-H187 cell than those against KB and MCF-7 cells. Results revealed that compounds 4, 6 and 7 possessed potent cytotoxic activity against the NCI-H187 cell with an $\mathrm{IC}_{50}$ value of $0.12,0.90$ and $0.72 \mu \mathrm{g} / \mathrm{mL}$, respectively. In addition, compound 4 showed higher cytotoxicity than a positive control, ellipticine ( $\mathrm{IC}_{50} 0.44 \mu \mathrm{g} / \mathrm{mL}$ ) which agree with previous reported [10]. Its toxicity was undetectable at concentration less than $50 \mu \mathrm{g} / \mathrm{mL}$ and very selective for NCI-H187 cell. Furthermore, compound 7 was also possessed potent cytotoxic activity against the KB cell and moderate activity against the MCF7 cell with an $\mathrm{IC}_{50}$ value of with an $\mathrm{IC}_{50}$ value of 0.92 and $2.89 \mu \mathrm{g} / \mathrm{mL}$, respectively. However, compound 7 was very toxic to Vero cells $\left(\mathrm{IC}_{50} 5.37 \mu \mathrm{g} / \mathrm{mL}\right)$ and not selective for tested cell lines. Compounds 2, 3, 5, 8 and 9 showed weak to no effect, while 1 and 10 showed moderate to weak effect on all tested cell lines. It should be noted that compound $\mathbf{1}$ has been reported to exhibit moderate cytotoxicity against P388, B16 and SNU-1 cells with $\mathrm{IC}_{50} 10.0,18.8$ and $8.0 \mu \mathrm{g} / \mathrm{mL}$ [19] but weak cytotoxicity against NCI-H187 cell with $\mathrm{IC}_{50} 49.73 \mu \mathrm{M}$ [10]. Compounds 5 and 8 have been reported to exhibit cytotoxic activity against V-79 cell with $\mathrm{IC}_{50} 18.5$ and $17.0 \mu \mathrm{g} / \mathrm{mL}$, respectively [5,12]. Compound 8 exhibited weaker cytotoxic activity against $\mathrm{KB}(40.01 \mu \mathrm{g} / \mathrm{mL})$ and NCI-H187 $(25.72 \mu \mathrm{g} / \mathrm{mL})$ cells than previous reported which showed moderate activities with $\mathrm{IC}_{50}$ 14.7 and $9.8 \mu \mathrm{g} / \mathrm{mL}$ [8]. However, it has been reported to displayed potent cytotoxic activity against A-549 cell line with the $\mathrm{LC}_{50}$ value of $14.0 \mu \mathrm{M}$ and weak cytotoxicity against SK-N-SH, MCF-7 and HeLa cells with $\mathrm{LC}_{50}$ 32.0, 21.9 and $60.6 \mu \mathrm{M}$, respectively [12]. To the best of our knowledge, this is the first report for the cytotoxic activities of compounds 2, 3, 6, 7, 9 and 10. On comparing the cytotoxic activity of compounds 1-10, drastic decrease or lack in cytotoxicity of compounds 1-3, 5, 8 and 9 against tested cell lines, implying that an $\alpha, \beta$-unsaturated $\gamma$-lactone ring plays a crucial role in mediating cytotoxic activity. Furthermore, change in the lactone moiety did affect the cytotoxicity. In a comparison of compound 4 with 6 and 10, the hydroxyl or methoxyl substitution at C-15 significantly reduced the cytotoxicity against all the tested cells. Nevertheless, among the compounds 7 and 10, the orientation of cyclic hemiacetal $\alpha, \beta$-unsaturated $\gamma$-lactone also influenced the cytotoxicity against all the tested cells. This is similar to their cytotoxicities against K562 cancer cell lines which was reported previously [6]. It is noteworthy to mention that the hydroxyl group at C-16 significantly enhanced the cytotoxicity of compound 7 against KB and MCF-7 cell lines, which suggested that the relative hydrophilicity of this part of the molecule contributes to the cytotoxicity. However, the lack of trans double bond conjugated with the lactone ring seemed to decrease cytotoxic activity, as indicated in the case of compound $\mathbf{1 0 .}$

\section{Materials and Methods}

\subsection{General Experimental Procedures}

Thin layer chromatography (TLC): precoated silica gel $60 F_{254}$ plates (0.2 mm thick; Merck). The TLC spots were visualized under UV light and by heating the plates after spraying with anisaldehyde- $\mathrm{H}_{2} \mathrm{SO}_{4}$ reagent. Column chromatography (CC): $\mathrm{SiO}_{2}$ (finer than $0.063 \mathrm{~mm}$; Merck), Sephadex LH-20 (Merck). Melting points: Electrothermal apparatus, uncorrected. Optical rotations: JASCO-1020 polarimeter. IR spectra: Tensor 27 FT-IR Spectrophotometer; KBr pellets. ${ }^{1} \mathrm{H}-$ and ${ }^{13}$ C-NMR spectra: Bruker AVANCE $400 \mathrm{NMR}$ spectrometer (400 and $100 \mathrm{MHz}$, resp.). HREIMS: Q-TOF $2^{\mathrm{TM}}$ mass spectrometer with a Z-spray ${ }^{\mathrm{TM}}$ ES source (Micromass, Manchester, UK). EI-MS: Agilent-HP 5973 mass spectrometer. 


\subsection{Plant Material}

The rhizomes of H. ellipticum were collected from Chiang Mai province of Thailand, in January 2007. A voucher specimen (06-609 J.F. Maxwell) was deposited with the CMU Herbarium, Department of Biology, Faculty of Science, Chiang Mai University, Thailand.

\subsection{Extraction and Isolation}

Air-dried powdered rhizome (920 g) of $H$. ellipticum was successively extracted with $n$-hexane and $\mathrm{CH}_{2} \mathrm{Cl}_{2}(4 \mathrm{~L} \times 3)$ at room temperature. The solvents were combined and evaporated to dryness under reduced pressure to yield a brownish residue of $n$-hexane $(44.26 \mathrm{~g})$ and $\mathrm{CH}_{2} \mathrm{Cl}_{2}(39.50 \mathrm{~g})$ extracts. The $n$-hexane $\left(44.26 \mathrm{~g}\right.$ ) extract was subjected to $\mathrm{CC}$ (n-hexane $/ \mathrm{CH}_{2} \mathrm{Cl}_{2}$ 100:1 to $0: 1$, gradient) to furnish five fractions, Frs. H1-H5. Fr. H1 (5.15 g) was successively subjected to CC ( $n$-hexane) to afford compound 1 (2.84 g). Fr. $\mathrm{H} 2(4.18 \mathrm{~g})$ was successively subjected to CC ( $n$-hexane/ $\mathrm{CH}_{2} \mathrm{Cl}_{2}$ 100:1) to yield four fractions, Frs. H2.1-H2.4. Fr. H2.4 (1.6 g) was further separated by CC ( $n$-hexane/EtOAc 98:2) to give five fractions, $\mathrm{H2}$.4a-H2.4e. Fr. $\mathrm{H2}$.4e was further purified by CC ( $n$-hexane/EtOAc 98:2) to afford compound $2(35.8 \mathrm{mg})$. Fr. $\mathrm{H} 4(8.60 \mathrm{~g})$ was successively subjected to $\mathrm{CC}\left(\mathrm{CH}_{2} \mathrm{Cl}_{2}\right)$ to yield four fractions, Frs. H4.1-H4.4. Fr. $\mathrm{H} 4.4(3.8 \mathrm{~g})$ was further separated by CC $\left(\mathrm{CH}_{2} \mathrm{Cl}_{2} / \mathrm{MeOH} 98: 2\right)$ to give three fractions, $\mathrm{H4} .4 a-H 4.4 c$. Fr. $H 4.4 b(1.1 \mathrm{mg}$ ) was further purified by CC ( $n$-hexane/EtOAc 98:2) to afford compound $3(20.1 \mathrm{mg})$. The $\mathrm{CH}_{2} \mathrm{Cl}_{2}$ extract $(39.50 \mathrm{~g})$ was subjected to a quick column $\left(\mathrm{SiO}_{2}\right.$ finer than 0.045 mm n-hexane/ $\mathrm{CH}_{2} \mathrm{Cl}_{2}$ 100:0 to 0:100, $\mathrm{CH}_{2} \mathrm{Cl}_{2} / \mathrm{EtOAc} 95: 5$ to 0:100), EtOAc/MeOH 95:5 to 50:50, gradient) to yield five fractions, Frs. C1-C5. Fr. C3 (7.85 g) was further separated by CC (n-hexane $/ \mathrm{CH}_{2} \mathrm{Cl}_{2}$ 60:40) to give three subfractions, C3.1-C3.3. Fr. C3.2 (2.9 g) was further purified by $\mathrm{CC}$ (n-hexane $/ \mathrm{CH}_{2} \mathrm{Cl}_{2}$ 60:40) to give three subfractions, Frs. C3.2a-C3.2c. Compound 4 (216.2 mg) was crystallized directly with $\mathrm{CH}_{2} \mathrm{Cl}_{2} / n$-hexane from $\mathrm{Fr}$. C3.2c $(1.8 \mathrm{~g})$. Fr. $\mathrm{C} 3.3(1.2 \mathrm{~g})$ was further separated by $\mathrm{CC}\left(\mathrm{CH}_{2} \mathrm{Cl}_{2} 100 \%\right)$ to give three fractions, Frs. C3.3a-C3.3c. Fr. C3.3b $(225.4 \mathrm{mg})$ was further purified by CC ( $n$-hexane/EtOAc 90:10) to afford compound 5 (45.9 mg). Fr. C4 (16.42 g) was further separated by $\mathrm{CC}\left(\mathrm{CH}_{2} \mathrm{Cl}_{2} / \mathrm{MeOH} 97: 3\right)$ to give Frs. $\mathrm{C} 4.1$ and C4.2. Fr. C4.1 (6.8 g) was rechromatographed by CC (n-hexane/EtOAc 80:20) to give three subfractions, Frs. C4.1a-C4.1c. Fr. C4.1a (2.1 g) was further purified by $\mathrm{CC}\left(\mathrm{CH}_{2} \mathrm{Cl}_{2} / \mathrm{MeOH} 97: 3\right)$ to give four subfractions, Frs. C4.1a1-C4.1a4. Fr. C4.1a3 (0.9 g) was further purified by CC ( $n$-hexane/EtOAc 80:20) to afford compounds 6 ( $35.8 \mathrm{mg}$ ) and 7 (57.8 mg). Fr. C4.1a4 (0.7 g) was further separated by CC ( $n$-hexane/EtOAc 70:30) to afford compounds 8 $(23.8 \mathrm{mg})$ and $9(11.3 \mathrm{mg})$. Fr. C4.2 (5.6 g) was separated by CC $\left(\mathrm{CH}_{2} \mathrm{Cl}_{2} / \mathrm{MeOH} 97: 3\right)$ to give three fractions, C4.2a-C4.2c. Fr. C4.2b (1.4 g) was further purified by CC (Sephadex LH-20; MeOH) to afford compound $\mathbf{1 0}(41.7 \mathrm{mg})$. All compounds 1-10 were identified by interpretation of their spectral data including EIMS, ${ }^{1} \mathrm{H}$ - and ${ }^{13} \mathrm{C}-\mathrm{NMR}$ (including DEPT135, COSY, HMQC and HMBC experiments), as well as by comparison of their spectral data with those reported in the literature. (NMR data of all compounds are given in the Supplementary Materials).

\subsection{Antimycobacterial Activity}

The antimycobacterial activity was assessed against Mycobacterium tuberculosis $\mathrm{H}_{37} \mathrm{Ra}$ using the green fluorescent protein microplate assay (GFPMA) [20]. The lowest drug concentration effecting and inhibition of $\geqslant 90 \%$ was considered the MIC. The standard drugs, rifampicine, streptomycin, isoniazid, oflaxacin and ethambutol showed MIC values of $0.00312-0.025,0.156-0.313,0.0234-0.0468,0.391-0.781$ and $0.234-0.469 \mu \mathrm{g} / \mathrm{mL}$, respectively.

\subsection{Cytotoxic Activity}

The cytotoxicity against human tumor cells was determined by resazurin microplate assay (REMA) which was a modified method of the use of a fluorescent dye for mammalian cell cytotoxicity [21]. The cytotoxicity against non-cancerous cells, African green monkey kidney (Vero) cell line was determined by the green fluorescent protein (GFP) detection [22]. Briefly, cells at a logarithmic growth phase were 
harvested and diluted to $9 \times 10^{4}$ cells $/ \mathrm{mL}$ in fresh medium. Successively, $5 \mu \mathrm{L}$ of test sample, diluted in $10 \%$ DMSO and $45 \mu \mathrm{L}$ of cells suspension were added to 384-well plates. Plates were incubated at $37^{\circ} \mathrm{C}$ in $5 \% \mathrm{CO}_{2}$ incubator for 5 days. After that, $12.5 \mu \mathrm{L}$ of $62.5 \mu \mathrm{g} / \mathrm{mL}$ resazurin solution was added to each well and the plates were then incubated at $37^{\circ} \mathrm{C}$ for $4 \mathrm{~h}$. Fluorescence signal was measured using SpectraMax M5 multidetection microplate reader at dual wavelengths of 530 and $590 \mathrm{~nm}$. For non-cancerous cells such as the African green monkey kidney (Vero) cell line, the cytotoxicity was determined by the green fluorescent protein (GFP) detection [22]. Briefly, cells at a logarithmic growth phase were harvested and diluted to $3.3 \times 10^{4}$ cells $/ \mathrm{mL}$ in fresh medium. Successively, $5 \mu \mathrm{L}$ of test sample, diluted in $0.5 \%$ DMSO and $45 \mu \mathrm{L}$ of cells suspension were added to 384 -well plates. Plates were incubated at $37{ }^{\circ} \mathrm{C}$ in $5 \% \mathrm{CO}_{2}$ incubator for 4 days. Fluorescence signals were measured on day zero, for subsequent background subtraction, and on day 4 using SpectraMax M5 multi-detection microplate reader in the bottom-reading mode with excitation and emission wavelengths of 485 and $535 \mathrm{~nm}$. IC 50 values were derived from dose-response curves, using six concentrations of 2-fold serially diluted samples, by the SOFTMax Pro software (Molecular device). The standard drugs ellipticine exhibited $\mathrm{IC}_{50}$ values against KB, NCI-H187 and Vero cell at $0.302,0.440$ and $1.345 \mu \mathrm{g} / \mathrm{mL}$ and doxorubicin exhibited $\mathrm{IC}_{50}$ values against MCF7 at $0.663 \mu \mathrm{g} / \mathrm{mL}$. The selectivity index corresponded to the $\mathrm{IC}_{50}$ value determined for cytotoxicity of isolated compounds on Vero cells divided by the $\mathrm{IC}_{50}$ determined for cancer cells.

\section{Conclusions}

We showed a low antimycobacterial activity and demonstrated the cytotoxic activities of some compounds among those isolated. The cytotoxicity results provided baseline information for the possible use of villosin (4), 15-methoxylabda-8(17),11,13-trien-15,16-olide (6) and 16-hydroxylabda8(17),11,13-trien-15,16-olide (7) for the development of antitumor drugs. All compounds were identified from this plant for the first time and compounds $(E)-15,16$-bisnorlabda-8(17),11-dien-13-one (2), (E)-14,15,16-trinorlabda-8(17),11-dien-13-oic acid (3), 16-hydroxylabda-8(17),11,13-trien-15,16-olide (7), zerumin A (9) and B (10) have not been isolated from any species of Hedychium. The isolation and identification of 10 compounds provide the first significant phytochemical report for this plant species and may be used as a foundation for further chemotaxonomic studies. The resulting information would be of some significance for drug discovery and development research and for further studies on the genus.

Supplementary Materials: Supplementary materials can be accessed at: http://www.mdpi.com/1420-3049/ 21/6/749/s1.

Acknowledgments: Financial support of the Bioresources Research Network, National Center for Genetic Engineering and Biotechnology (grant no. BRN009 G-52) and Centre of Excellence for Innovation in Chemistry (PERCH-CIC) are gratefully acknowledged.

Author Contributions: Sineenard Songsri performed the experiments and analyzed the data; Nuchnipa Nuntawong designed the experiments, analyzed the data and wrote the paper.

Conflicts of Interest: The authors declare no conflict of interest.

\section{References}

1. Xiao, P.; Sun, C.; Zahid, M.; Ishrud, O.; Pan, Y. New diterpene from Hedychium villosum. Fitoterapia 2001, 72, 837-838. [PubMed]

2. Matsuda, H.; Morikawa, T.; Sakamoto, Y.; Toguchida, I.; Yoshikawa, M. Antiinflammatory principles and three new labdane-type diterpenes, hedychilactones A, B, and C, from the rhizome of Hedychium coronarium Koeng. Heterocycles 2002, 56, 45-50.

3. Nakamura, S.; Okazaki, Y.; Ninomiya, K.; Morokawa, T.; Matsuda, H.; Yoshikawa, M. Medicinal Flowers. XXIV. Chemical structures and hepatoprotective effects of constituents from flowers of Hedychium coronarium. Chem. Pharm. Bull. 2008, 56, 1704-1709. [PubMed] 
4. Matsuda, H.; Morikawa, T.; Sakamoto, Y.; Toguchida, I.; Yoshikawa, M. Labdane-type diterpenes with inhibitory effects on increase in vascular permeability and nitric oxide production from Hedychium coronarium. Bioorg. Med. Chem. 2002, 10, 2527-2534. [PubMed]

5. Itokawa, H.; Morita, H.; Katou, I.; Takeya, K.; Cavalheiro, A.J.; de Oliveira, R.C.B.; Ishige, M.; Motidome, M. Cytotoxic diterpenes from the rhizomes of Hedychium coronarium. Planta Med. 1988, 54, 311-315. [PubMed]

6. Zhao, Q.; Qing, C.; Hao, X.J.; Han, J.; Zuo, G.Y.; Zou, C.; Xu, G.L. Cytotoxicity of labdane-type diterpenoids from Hedychium forrestii. Chem. Pharm. Bull. 2008, 56, 210-212. [PubMed]

7. Zhao, H.; Zeng, G.; Zhao, S.; Xu, J.; Kong, L.; Li, Y.; Tan, N.; Yang, S. Cytotoxic labdane-type diterpenes from Hedychium longipetalum inhibiting production of nitric oxide. Bioorg. Med. Chem. Lett. 2015, 25, 4572-4575. [CrossRef] [PubMed]

8. Chimnoi, N.; Pisutjaroenpong, S.; Ngiwsara, L.; Dechtrirut, D.; Chokchaichamnankit, D.; Khunnawutmanotham, N.; Mahidol, C.; Techasakul, S. Labdane diterpenes from the rhizomes of Hedychium coronarium. Nat. Prod. Res. 2008, 22, 1249-1256. [PubMed]

9. Reddy, P.P.; Rao, R.R.; Rekha, K.; Babu, K.S.; Shashidhar, J.; Shashikiran, G.; Lakshmi, V.V.; Rao, J.M. Two new cytotoxic diterpenes from the rhizomes of Hedychium spicatum. Bioorg. Med. Chem. Lett. 2009, 19, 192-195. [CrossRef] [PubMed]

10. Kumrit, I.; Suksamrarn, A.; Meepawpan, P.; Songsri, S.; Nuntawong, N. Labdane-Type Diterpenes from Hedychium gardnerianum with potent cytotoxicity against human small cell lung cancer cells. Phytother. Res. 2010, 24, 1009-1013. [PubMed]

11. Suresh, G.; Poornima, B.; Babu, K.S.; Yadav, P.A.; Rao, M.S.A.; Siva, B.; Prasad, K.R.; Nayak, V.L.; Ramakrishna, S. Cytotoxic sesquiterpenes from Hedychium spicatum: Isolation, structure elucidation and structure-activity relationship studies. Fitoterapia 2013, 86, 100-107. [CrossRef] [PubMed]

12. Suresh, G.; Reddy, P.P.; Suresh, K.B.; Thokhir, B.S.; Shasi, V.K. Two new cytotoxic labdane diterpenes from the rhizomes of Hedychium coronarium. Bioorg. Med. Chem. Lett. 2010, 20, 7544-7548. [CrossRef] [PubMed]

13. Van Thnah, B.; Dai, D.N.; Thang, T.D.; Binh, N.Q.; Anh, L.D.N.; Ogunwande, I.A. Composition of essential oils of four Hedychium species from Vietnam. Chem. Cent. J. 2014, 8, 1-5.

14. Joshi, S.; Chanotiya, C.S.; Aganwal, G.; Prakash, D.; Pant, A.K.; Mathela, C.S. Terpenoid compositions and antioxidant and antimicrobial properties of the rhizome essential oils of different Hedychium species. Chem. Biodivers. 2008, 5, 299-309. [CrossRef] [PubMed]

15. Kumar, S.; Ziereis, K.; Wiegrebe, W.; Muller, K. Medicinal plants from Nepal: Evaluation as inhibitors of leukotriene biosynthesis. J. Ethnopharmacol. 2000, 70, 191-195. [CrossRef]

16. Itokawa, H.; Morita, H.; Mihashi, S. Labdane and bisnorlabdane type diterpenes from Alpinia speciosa K. SCHUM. Chem. Pharm. Bull. 1980, 28, 3452-3454. [CrossRef]

17. Kiem, P.V.; Anh, H.L.T.; Nguyen, X.N.; Minh, C.V.; Nguyen, T.K.T.; Yen, P.H.; Hang, D.T.; Tai, B.H.; Mathema, V.B.; Koh, Y.S. Labdane-type diterpenoids from the rhizomes of Hedychium coronarium inhibit lipopolysaccharide-stimulated production of proinflammatory cytokines in bone marrow-derived dendritic cells. Chem. Pharm. Bull. 2012, 60, 246-250. [CrossRef] [PubMed]

18. Xu, H.X.; Hui, D.; Sim, K.Y. Labdane diterpenes from Alpinia zerumbet. Phytochemistry 1996, 42, $149-151$.

19. Jung, M.; Ko, I.; Lee, S.; Choi, S.J.; Youn, B.H.; Kim, S.K. A concise synthesis and in vitro cytotoxicity of new labdane diterpenes. Bioorg. Med. Chem. Lett. 1998, 8, 3295-3298. [CrossRef]

20. Changsen, C.; Franzblan, S.; Palittapongarnpim, P. Improved green fluorescent protein reporter gene-based microplate screening for antituberculosis compounds by utilizing an acetamidase promoter. Antimicrob. Agents Chemother. 2003, 47, 3682-3687. [CrossRef] [PubMed]

21. O'Brien, J.; Wilson, I.; Orton, T.; Pognan, F. Investigation of the Alamar Blue (resazurin) fluorescent dye for the assessment of mammalian cell cytotoxicity. Eur. J. Biochem. 2000, 267, 5421-5425. [CrossRef] [PubMed]

22. Hunt, L.; Jordan, M.; de Jesus, M.; Wurm, F.M. GFP-expressing mammalian cells for fast, sensitive, noninvasive cell growth assessment in a kinetic mode. Biotechnol. Bioeng. 1999, 65, 201-205. [CrossRef]

Sample Availability: Samples of the compound $\mathbf{1}$ is available from the authors.

(C) 2016 by the authors; licensee MDPI, Basel, Switzerland. This article is an open access article distributed under the terms and conditions of the Creative Commons Attribution (CC-BY) license (http://creativecommons.org/licenses/by/4.0/). 